\title{
Ovine White-Liver Disease (OWLD). Botanical and Chemical Composition of Pasture Grass
}

\author{
By Martha J. Ulvund and Markus Pestalozzi
}

State Veterinary Research Station for Small Ruminants, Sandnes, and State Agricultural Research Station, Klepp st., Norway.

\begin{abstract}
Ulvund, M. J. and M. Pestalozzi: Ovine white-liver disease (OWLD). Botanical and chemical composition of pasture grass. Acta vet. scand. 1990, 31, 257-265. The most important grass species on the ovine white-liver disease (OWLD) pastures (S) were Poa spp., Agropyron repens and Lolium perenne, while the control pastures (H), where lambs grew well, consisted of Poa spp., Festuca rubra and Agrostis tenuis. The soil was more acidic on the $\mathrm{H}$ pastures as compared with the $\mathrm{S}$ pastures. OWLD grass ( $\mathrm{S}$ grass) contained marginal to deficient amounts of cobalt during the first 2 months of grazing. During 2 years out of 3 , the average Co content was slightly lower in the $\mathrm{S}$ grass as compared with the content in the $\mathrm{H}$ grass. The lowest average grass Co was, however, found during one year in the $\mathrm{H}$ grass, in spite of the fact that the $\mathrm{H}$ lambs also this year grew well, and were $13 \mathrm{~kg}$ heavier than the $\mathrm{S}$ lambs after $31 / 2$ months on pasture. Results thus indicate that the $\mathrm{H}$ lambs some years were subclinically Co deficient, without developing clinical symptoms or OWLD, and that factors other than marginal/deficient grass Co are of importance as to whether OWLD will develop or not. $\mathrm{S}$ grass differed from $\mathrm{H}$ grass by having significantly lower copper, molybdenum, manganese and zinc content, lower protein $\mathrm{N} / \mathrm{amid} \mathrm{N}$ ratios and higher aluminium and iron contents. According to the results, marginal to deficient grass Co is essential for development of OWLD, but cofactors play a part.
\end{abstract}

sheep; cobalt/vitamin $B_{12}$ deficiency; trace elements.

\section{Introduction}

Clinical symptoms of ovine white-liver disease (OWLD) and the effect of prophylactic measures were described in a previous publication (Ulvund \& Pestalozzi 1990). OWLD has been found in lambs grazing various grass species, either containing adequate amounts of cobalt (Sutherland 1978, Clark et al. 1978, Richards \& Harrison 1981), or being marginal to deficient in Co (Sutherland 1978, Sutherland et al. 1979, Mitchell et al. 1982, Mason \& McKay 1983 and McLoughlin et al. 1984). Martinovich (1974) suggested that OWLD might be due to mycotoxic effect in $\mathrm{Co} / \mathrm{B} 12$ deficient lambs, while Sutherland et al. (1979) proposed that high amounts of dietary precursors of propionic acid might be significant.

Plants containing mycotoxins or alkaloids may cause illthrift and hepatotoxicity in sheep (Gardiner 1965, Seaman 1987). Illthrift has occurred in lambs grazing reed canarygrass (Phalaris arundinacea) containing the alkaloid gramine (Marten et al. 1976). In our area, phalaris stagger in lambs grazing reed canarygrass has been described (Ulvund 1985).

It was therefore of interest to clarify the botanical and chemical composition of OWLD grass as well as grass from pastures where 
lambs grow well, with special reference to trace elements and gramine.

\section{Materials and methods}

Experimental design has been described (Ulvund \& Pestalozzi 1990). All pastures were located on morainic soil with sand as dominating fraction. The OWLD pastures (S) were on deep drought resistant top soil, on ploughed land, seeded 14-30 years ago. The control pastures $(\mathrm{H})$, where lambs have been thriving well for years, were situated 15 $\mathrm{km}$ apart, and were on surface cultivated hilly terrain with varying humus content in the soil. The pastures were situated in southwestern Norway, 50-100 m above sea level, and 2-6 km from the sea.

Details of fertilization are given in Table 1. Each year, about 40 times as much calcium, 6 times as much sulphur, and twice as much nitrogen, phosphorous and potassium were used per ha on the $\mathrm{S}$ pastures as compared with the $\mathrm{H}$ pastures. Parts of the pastures were fertilized with Co (Table 2).

Table 1. Fertilization of pastures. Total amount of elements used each year on the OWLD pastures $(\mathrm{S})$, and the control $(\mathrm{H})$ pastures $(\mathrm{kg} / \mathrm{ha})$.

\begin{tabular}{lcc}
\hline Element & S pasture & H pasture \\
\hline $\mathrm{N}$ & 205 & $130-180$ \\
$\mathrm{P}$ & 30 & $15-20$ \\
$\mathrm{~K}$ & 100 & $35-45$ \\
$\mathrm{Mg}$ & 13 & $6-8$ \\
$\mathrm{~S}$ & 60 & $8-10$ \\
$\mathrm{Ca}$ & 370 & $8-10$ \\
$\mathrm{Cu}$ & 0.7 & 0 \\
$\mathrm{~B}$ & 0 & $0.03-0.04$ \\
\hline
\end{tabular}

On the S pastures $650 \mathrm{~kg}$ PK fertilizer (5-16) was used in early spring, and $700+500+400 \mathrm{~kg}$ calcium nitrate $(15.5 \% \mathrm{~N})$ during the grazing season (MayOctober). The $\mathrm{H}$ pastures were fertilized with commercial NPK fertilizer (25-3-6) 3-4 times during the grazing season, and about $180 \mathrm{~kg}$ per ha was used each time.
Rainfall figures and temperatures were obtained from the nearest meteorological station Sola, $12 \mathrm{~km}$ from the S pastures, and 14 $\mathrm{km}$ from the $\mathrm{H}$ pastures. The range in mean monthly temperatures during the grazing period (May-September) for the years 1981-1986 was $8-15^{\circ} \mathrm{C}$. The mean yearly temperature during these years was $7.1^{\circ} \mathrm{C}$, which was close to the 30 -year normal (1931-1960) of $7.4^{\circ} \mathrm{C}$. Total annual precipitation varied from 979 to $1417 \mathrm{~mm}$, overall mean was $1255 \mathrm{~mm}$. The years 1981-1983 and 1986 had an annual rainfall above 1350 $\mathrm{mm}$, while 1984-1985 had below $990 \mathrm{~mm}$. The 30-year normal annual precipitation for the area is $1015 \mathrm{~mm}$.

The $\mathrm{pH}$ of the soil was examined in 1978 and 1988. In 1978, $\mathrm{pH}$ was on average 5.2 (5.1-5.3) on the $\mathrm{H}$ pastures, and 5.5 on the $\mathrm{S}$ pastures, while ten years later, it was 4.7 $(4.6-4.7)$ on the $\mathrm{H}$ pastures, and 6.1 on the $S$ pastures.

The botanical composition was examined in 1978 by fencing off with cage net $6 \times 1 \mathrm{~m}^{2}$ on each pasture. The swards were cut in July, sorted in species and dried.

Grass samples for chemical analysis were taken 3 times during the grazing season (Table 2). Multiple small portions of grass from all quadrants of each pasture were cut and mixed, and approximately $1 \mathrm{~kg}$ from each plot was dried for 48 hours at $60^{\circ} \mathrm{C}$. Efforts were made to avoid soil contamination. The samples collected in 1982 were frozen $\left(-20^{\circ} \mathrm{C}\right)$. For gramine estimations samples of $0.1 \mathrm{~kg}$ fresh grass were frozen.

$\mathrm{Co}$ and other metal concentrations were determined by simultaneous multi-element analysis in a d.c. plasma-atomic emission spectrometer by SVA-Uppsala (Frank \& Petersson 1983). Ås-NLH used the following methods: Flameless atomic absorption spectrophotometry (AAS, grafite oven) for $\mathrm{Cu}$ determination, flame AAs for Mn determi- 
Table 2. Survey of grass samples examined. Year of sampling, pasture of origin, parameters examined, and performing laboratory are given. Three different grass samples were taken from each pasture every year, during week 21 (May), 26 (June) and 32 (Aug.).

\begin{tabular}{llll}
\hline Year & Pasture & Parameters & Laboratory \\
\hline 1982 & S, SCo, H & Mn, Cu, Mo, tot. S: & As-NLH \\
1983 & S, SCo, H & $\begin{array}{l}\text { Mn, Cu, Mo, tot. S, amino- } \\
\text { acid-S, tot. N, prot. N: } \\
\end{array}$ & As-NLH \\
1984 & S, SCo, H & $\begin{array}{l}\text { Mn, Cu, Mo, tot. S, Fe, } \\
\text { tot. N, prot. N: }\end{array}$ & As-NLH \\
& & Co: & SVA \\
1985 & S, SCo, & Tot. N, prot. N, tot. S: & As-NLH \\
& SCo+, H & Co, Mn, Cu, Fe, Zn: & SVA \\
& & Mo, Se: & NVI \\
& & P: & CVM \\
& & Gramine: & SF-Fureneset \\
1986 & S, SCo, & Co, Mn, Cu, Mo, Fe, Zn, Mg, \\
& SCo+, H & Ca, Pb, Al, P, Tot. S: & SVA \\
& HCo & Gramine: & SF-Fureneset \\
\hline
\end{tabular}

The OWLD pastures are designated S. SCo are S pastures Co fertilized in 1980, 1981 and 1982, while SCo+ pastures were Co fertilized 1980, 1981, 1982, 1985 and $1986\left(\mathrm{CoSO}_{4}, 1 \mathrm{~kg} / \mathrm{ha}\right)$. Control pastures are designated $\mathrm{H}$, and $\mathrm{HCo}$ are $\mathrm{H}$ pastures $\mathrm{Co}$ fertilized in $1986\left(\mathrm{CoSO}_{4}, 2 \mathrm{~kg} / \mathrm{ha}\right)$.

Ås-NLH : Chemical Research Laboratory, Agricultural University of Norway.

SVA : National Veterinary Institute, Uppsala, Sweden.

NVI : National Veterinary Institute, Oslo, Norway.

CVM : Department of Biochemistry, Norwegian College of Veterinary Medicine, Oslo, Norway.

SF : Fureneset Research Station, Norwegian State Agricultural Research Stations, Fure, Norway.

nation, Mo was examined by spectrophotometry, total sulphur by spectrophotometric determination of turbidity (BaSO $_{4}$-suspension), Kjeldahl-N according to Kjeldahl's method modified for Tecator Kjeltec with $\mathrm{CuO}$ as catalyst, and pure protein-N according to Barnstein-Stutzer method modified for Tecator Kjeltec (Halvorsen 1989). Co analyses were also performed in 1981-1983, with flameless AAS, but because of technical reasons the results were unreliable and had to be excluded. NVI-
Oslo used flameless AAS for the determination of molybdenum, and a fluorimetric method for the determination of selenium (Norheim 1989). Gramine was examined according to Simons \& Marten (1971), as described by Østrem (1987).

Blind parallels were included and the divergence in results was within acceptable limits. Estimates of the $\mathrm{Cu}$ availability $\left(\mathrm{A}_{\mathrm{Cu}}, \%\right)$ and absorbability ( $\mathrm{Abs}_{\mathrm{Cu}}$ ) were made according to Suttle (1983). Statistical testing of differences was made by one way analysis of var- 
iance (Snedecor \& Cochran 1967). Least significant difference (LSD) was calculated only when $F$ was significant.

Table 3. Cobalt contents ( $\mathrm{mg} / \mathrm{kg} \mathrm{DM}$, activation analysis) in pasture grass sampled in week no. 21 , 26 , and 32 for the years 1984-1986. For explanation of pasture symbols, see footnote of Table 2.

\begin{tabular}{ccccccc}
\hline Year & $\begin{array}{c}\text { Week } \\
\text { no. }\end{array}$ & S & SCo & SCot & H & HCo \\
\hline 1984 & 21 & 0.15 & 0.16 & - & 0.24 & - \\
& 26 & 0.13 & 0.18 & - & 0.17 & - \\
& 32 & 0.16 & 0.22 & - & 0.27 & - \\
1985 & 21 & 0.10 & 0.47 & 0.45 & 0.16 & - \\
& 26 & 0.08 & 0.16 & 0.28 & 0.09 & - \\
& 32 & 0.11 & 0.22 & 0.39 & 0.21 & - \\
1986 & 21 & 0.09 & 0.12 & 1.70 & 0.09 & 1.34 \\
& 26 & 0.09 & 0.14 & 0.37 & 0.10 & 1.05 \\
& 32 & 0.17 & 0.15 & 0.32 & 0.06 & 0.64 \\
\hline
\end{tabular}

\section{Results}

The most important grass species on the $\mathrm{S}$ pastures were Poa sp. (39\%), Agropyron repens $(27 \%)$ and Lolium perenne (16\%), and on the $\mathrm{H}$ pastures Poa sp. (68\%), Festuca rubra (11\%) and Agrostis tenuis (10\%).

During 2 years out of 3 , the average Co content was slightly lower in the $\mathrm{S}$ grass as compared with the $\mathrm{H}$ grass (Table 3 ). The lowest average grass Co was, however, found during 1 year (1986) in the $\mathrm{H}$ grass. Fertilizing the pastures with Co increased the content substantially the first years after treatment, but the effect decreased after 4 years.

The contents of $\mathrm{Mn}, \mathrm{Cu}$, Mo and $\mathrm{Zn}$ was significantly higher in $\mathrm{H}$ grass than in $\mathrm{S}$ grass, while the content of $\mathrm{Al}, \mathrm{Fe}$ and $\mathrm{Ca}$ was highest in $\mathrm{S}$ grass (Table 4). The $\mathrm{Cu} / \mathrm{Mo}$ ratios of the $\mathrm{S}$ grass were not significantly

Table 4. Total number of grass samples examined (n) from the $S, S C o$ and $H$ pastures and overall mean amount (in DM) of $\mathrm{Mn}, \mathrm{Cu}, \mathrm{Mo}, \mathrm{Fe}, \mathrm{Zn}, \mathrm{Al}(\mathrm{mg} / \mathrm{kg}$ ), $\mathrm{Ca}(\mathrm{g} / \mathrm{kg})$, approximate $\mathrm{Cu}$ availability $\left(\mathrm{A}_{\mathrm{Cu}}, \%\right)$ and protein N/amid N. Significance and least significant difference between these three pastures (LSD, 5 per cent), and significance of difference in sampling time are given. Mean values for samplings (S, SCo, H) performed during the same week each year are also given. For explanation of pasture types and years of sampling, see Table 2.

\begin{tabular}{lrcccccccc}
\hline & Mn & Cu & ACu & Mo & Fe & Zn & Ca & Al & $\begin{array}{c}\text { ProtN/ } \\
\text { AmidN }\end{array}$ \\
\hline n & 54 & 54 & 39 & 54 & 36 & 27 & 15 & 15 & 30 \\
S & 53 & 4.6 & 3.1 & 1.0 & 186 & 33 & 6.7 & 143 & 3.1 \\
SCo & 47 & 4.8 & 2.8 & 1.2 & 189 & 32 & 6.3 & 91 & 3.5 \\
(SCo+ & 57 & 4.5 & 2.9 & 1.1 & 144 & 32 & 5.9 & 61 & $3.3)$ \\
H & 133 & 6.8 & 2.3 & 1.6 & 106 & 40 & 3.3 & 29 & 4.5 \\
(HCo & 89 & 5.8 & - & 1.2 & 88 & 32 & 4.0 & 30 & $-)$ \\
Sign. & $* * *$ & $* * *$ & $* *$ & $* * *$ & $*$ & $*$ & & $*$ & $* *$ \\
LSD & 23 & 0.7 & 0.4 & 0.2 & 68 & 6 & ns & 78 & 0.6 \\
\hline May & 62 & 5.6 & 2.2 & 1.3 & 132 & 34 & 5.0 & 47 & 3.8 \\
June & 68 & 4.5 & 3.8 & 1.1 & 114 & 32 & 4.1 & 59 & 3.5 \\
Aug. & 94 & 5.7 & 2.3 & 1.4 & 206 & 36 & 6.7 & 106 & 3.8 \\
Sign. & $* *$ & $* * *$ & $* * *$ & $* *$ & $* *$ & ns & ns & ns & ns \\
\hline
\end{tabular}

For $\mathrm{SCo}$ and $\mathrm{HCo}$ (in brackets), adjusted mean values only represent samplings from one or two years.

Sign. = Significance levels, ns $>5,{ }^{*}<5,{ }^{* *}<1,{ }^{* * *}<0.1$ per cent. 
Table 5. Kjeldahl N, total sulphur (g/100 g DM), amino acid S, P (g/kg DM), $\mathrm{Mg}(\mathrm{mg} / \mathrm{kg} \mathrm{DM}), \mathrm{Se}, \mathrm{AbsCu}(\mu \mathrm{g} / \mathrm{kg} \mathrm{DM})$ and gramine $(\mu \mathrm{g} / \mathrm{g} \mathrm{DM})$ in pasture grass. $\mathrm{n}=$ total number of grass samples examined. Mean values \pm SD for all pastures and years are given.

\begin{tabular}{lcccccccc}
\hline & $\begin{array}{c}\text { Kjel- } \\
\text { dahl N }\end{array}$ & $\begin{array}{c}\text { Tot. } \\
\text { S }\end{array}$ & $\begin{array}{c}\text { Amino- } \\
\text { acid S }\end{array}$ & P & Mg & Se & AbsCu & Gramine \\
\hline n & 30 & 54 & 9 & 27 & 15 & 12 & 45 & 31 \\
mean & 35 & 29 & 1.7 & 3.6 & 1.6 & 16.6 & 140 & 70 \\
\pm SD & 0.8 & 8.0 & 0.2 & 0.7 & 0.2 & 10.0 & 50 & 43 \\
\hline
\end{tabular}

different from the ratios of the $\mathrm{H}$ grass, the overall values were 4.9 (S) as compared to $4.7(\mathrm{H})$. The availability of $\mathrm{Cu}\left(\mathrm{A}_{\mathrm{Cu}} \%\right)$ was significantly higher in $\mathrm{S}$ grass, while the calculated absorbable amount $\left(\mathrm{Abs}_{\mathrm{Cu}}\right)$ varied much in both $\mathrm{S}$ and $\mathrm{H}$ grass (Tables 4 and 5).

Fertilizing with Co decreased grass $\mathrm{Al}$, and partly also Ca. The protein $\mathrm{N}$ to amid $\mathrm{N}$ ratios were lower in $\mathrm{S}$ grass than in $\mathrm{H}$ grass, and Co fertilization seemed to increase the ratio (Table 4). The overall mean amount of $\mathrm{Pb}$ was $0.33 \mathrm{mg} / \mathrm{kg}$ in $\mathrm{S}$ grass, 0.27 in moderately Co fertilized $\mathrm{S}$ grass ( $\mathrm{SCo}$ ) and 0.18 in heavily Co fertilized $\mathrm{S}$ grass ( $\mathrm{SCo}+$ ). Corresponding amounts in $\mathrm{H}$ and $\mathrm{HCo}$ grass were 0.68 and $0.61 \mathrm{mg} / \mathrm{kg}$.

There were no significant differences between $\mathrm{S}$ and $\mathrm{H}$ grass regarding the content of Kjeldahl $\mathrm{N}$, total $\mathrm{S}$, amino acid $\mathrm{S}, \mathrm{P}, \mathrm{Mg}$, Se, $\mathrm{AbsCu}$ and gramine. Overall mean values of these elements are given in Table 5. The overall pure protein $\mathrm{N}$ content was 3.0 $(\mathrm{g} / 100 \mathrm{~g} \mathrm{DM})$ in $\mathrm{H}$ grass, and 2.7 and 2.5 in $\mathrm{S}$ and SCo grass respectively. The lowest amounts of most elements were found during week 26 (June, Table 4).

\section{Discussion}

Sandy soil, rainy climate, leafy pastures, dead litter and freely drained soil were characteristics of our $S$ pastures. These features have also been associated with
OWLD in other countries (Clark et al. 1978, Sutherland et al. 1979, Mason \& McKay 1983), as has pure Co deficiency (Andrews et al. 1958, Robertson 1971). The grass of the $\mathrm{H}$ pastures was less lush, and the soil poorer drained. The OWLD condition was mostly pronounced in 1981-1983 and 1986 (Ulvund \& Pestalozzi 1990), when the annual precipitation was highest.

OWLD has been found in lambs grazing ryegrass, Lolium perenne, (Mason \& McKay 1983), ryegrass, white clover (Trifolium repens) and kikuyu grass (Pennisetum clandestinum, Sutherland et al. 1979), or ryegrass, oat stubble, clover (Trifolium repens) and kikuyu grass (Richards \& Harrison 1981). Common for these and our OWLD pastures was the perennial ryegrass. Ryegrass may contain alkaloids (Grimmett \& Melville 1943), mycotoxins (Siegel et al. 1985) or bacteria and nematodes producing hepato-/ neurotoxins (Berry et al. 1982). Further examination of our ryegrass could therefore be a next step.

It is generally accepted that sheep require $0.11 \mathrm{mg} \mathrm{Co} / \mathrm{kg} \mathrm{DM}$, and mixed herbage on soil classified as adequate in Co normally contains $>0.10 \mathrm{mg} / \mathrm{kg}$ (Anon. 1980, Anon. 1982, Smith 1987). If the herbage consistently contains less than $0.08 \mathrm{mg} \mathrm{Co}$, Co/B12 deficiency will develop (Smith 1987). The Co content in our OWLD grass may thus be classified as normal to margi- 
nal/deficient, with marginal/deficient values in June each year. However, marginal/deficient values were also found in $\mathrm{H}$ grass. In 1986, when the Co content in $\mathrm{H}$ grass was lower than in $\mathrm{S}$ grass, the growth of the $\mathrm{H}$ lambs was on average $4 \mathrm{~kg}$ less than that of the 2 preceding years, indicating a subclinical Co deficiency (Ulvund \& Pestalozzi 1990). But still they were $13 \mathrm{~kg}$ heavier than the $\mathrm{S}$ lambs by September 1, and none developed clinical OWLD.

During later years $(1987,1988)$, the average Co content was also lower in $\mathrm{H}$ grass as compared with $\mathrm{S}$ grass, while the lambs grew very well (Ulvund \& Pestalozzi, unpublished). Thus it can be concluded that OWLD is not solely due to scarce grass Co. On the S pasture there was a certain correlation between Co content in the grass during the first 2 months of grazing and seriousness of OWLD. Lambs grazing $\mathrm{H}$ grass with similar Co values were, however, healthy and normally growing. The difference in growth rate between $\mathrm{H}$ and $\mathrm{S}$ lambs, and the development of OWLD was therefore not due to varying degree of simple Co deficiency within the grass.

Sutherland (1978) reported 8 outbreaks of OWLD in New Zealand, where none of the pastures contained more Co than 0.10 $\mathrm{mg} / \mathrm{kg}$, while Clark et al. (1978) found OWLD on pastures containing more than $0.16 \mathrm{mg} \mathrm{Co} / \mathrm{kg}$. In Australia, OWLD has been reported on pastures with normal Co contents (Richards \& Harrison 1981), marginal amounts $0.09-0.13 \mathrm{mg} / \mathrm{kg}$ (Mason \& McKay 1983), and on pastures being deficient $0.02 \mathrm{mg} / \mathrm{kg}$ (Mitchell et al. 1982). In Northern Ireland, OWLD occurred on a pasture containing $0.08 \mathrm{mg} \mathrm{Co} / \mathrm{kg}$ (McLoughlin et al. 1984).

Liming and high soil content of $\mathrm{Mn}$ and $\mathrm{Fe}$ may decrease the availability of soil Co to the grass, and an increase in soil PH may also reduce Co uptake (Anon. 1982, McLaren et al. 1987). The extensive use of Ca as well as the higher soil $\mathrm{pH}$ on the $\mathrm{S}$ pastures may therefore be of some significance regarding the Co content of the $\mathrm{S}$ grass. Simple Co deficiency is known to occur on soil rich in Ca (Robertson 1971), and coast disease, a concurrent deficiency of $\mathrm{Co}$ and $\mathrm{Cu}$, occurred on calcareous sandy soil containing windborne shell fragments in South Australia (Marston et al. 1938). Little is known about the details in this $\mathrm{Co} / \mathrm{Ca}$ interaction. As, however, the liver content of Co was equally marginal to deficient in both our OWLD lambs (S lambs) and $H$ lambs (Ulvund 1990a), any significant role of $\mathrm{Ca}$ in the present material is so far difficult to interpret.

The use of $\mathrm{Ca}$ on the $\mathrm{S}$ pastures may have reduced the amount of grass $\mathrm{Mn}$ as well. Mitchell et al. (1957) reported that liming of ryegrass reduced the mean $\mathrm{Mn}$ value from 140 to $120 \mathrm{mg} / \mathrm{kg}$. Any inhibitory effect of $\mathrm{Mn}$ on Co availability can probably be ruled out in our case. As minimum requirements of growing lambs are estimated to be about 20-25 mg Mn/kg (Anon. 1980, Anon. 1982), our S lambs probably got sufficient $\mathrm{Mn}$. High intakes of $\mathrm{Ca}$ in the diet may, however, have interfered with the intestinal absorption (Hurley \& Keen 1987), explaining the lower liver $\mathrm{Mn}$ seen in $\mathrm{S}$ lambs during some years (Ulvund 1990a).

High amounts of Fe may inhibit Co absorption from the intestine (Smith 1987). The low liver $\mathrm{Co}$ found in both $\mathrm{H}$ and $\mathrm{S}$ lambs indicates that the higher $\mathrm{Fe}$ content in $\mathrm{S}$ grass had no significance (Ulvund 1990a). Halpin et al. (1982) reported that sheep grazing plots receiving high applications of super phosphate had decreased plasma $\mathbf{B}_{12}$. The lack of difference between $\mathrm{S}$ and $\mathrm{H}$ grass in $\mathrm{P}$ content indicates that this effect cannot explain the occurrence of OWLD. 
Variations in $\mathrm{Cu}$ absorbability is great, and dependant on Mo, S, Fe, $\mathrm{Zn}, \mathrm{Ca}$ and breed (Davis \& Mertz 1987). In coastal districts in Norway, mean value of $\mathrm{Cu}$ in cultivated herbage was found to be $6.9 \mathrm{mg} / \mathrm{kg} \mathrm{DM}$ (Froslie \& Norheim 1983). Grass $\mathrm{Cu}$ decreases by liming, especially if the original content is scarce (Anon. 1982). This may have contributed to the lower $\mathrm{Cu}$ content in our $\mathrm{S}$ grass. Liver $\mathrm{Cu}$ was often deficient in the OWLD lambs, and most often lower than in the $\mathrm{H}$ lambs, although individual $\mathrm{H}$ lambs also had deficient amounts (Ulvund 1990a). A role of $\mathrm{Cu}$ in the OWLD pathogenesis can therefore not be excluded, but is discussed in detail elsewhere (Ulvund 1990a, b, c).

Grass Mo in our pastures were within similar ranges as reported by Froslie \& Norheim (1983), who found a mean value of 0.8 $\mathrm{mg} / \mathrm{kg} \mathrm{DM}$ in samples from coastal areas. Grass Mo may increase by liming and pasture improvement (Anon. 1982). Mills \& Davis (1987) report $0.2-0.8 \mathrm{mg} / \mathrm{kg}$ as representative amounts in grasses, with increased amounts concomitant with increases in soil $\mathrm{pH}$. The fact that $\mathrm{S}$ grass contained less Mo than $\mathrm{H}$ grass, in spite of higher soil $\mathrm{pH}$, probably reflects much lower soil Mo on the $\mathrm{S}$ pastures.

The $\mathrm{Cu} / \mathrm{Mo}$ ratios varied between 3 and 9.5 in our material. A balanced diet often contains a $\mathrm{Cu} / \mathrm{Mo}$ ratio of $5-10$, with a lower critical ratio of 2 , and an upper critical ratio of 20 (Froslie \& Norheim 1983).

The amount of sulphur found in our pastures was slightly higher than the amount found by Froslie \& Norheim (1983) in coastal grass. The increase may be due to pasture improvement (Anon. 1982). The $\mathrm{A}_{\mathrm{Cu}}$ and Abscu of our pastures were of the same magnitude as those recorded in summer pastures in Scotland (Suttle 1983).
Minimum requirements of $\mathrm{Zn}$ are about 15 $\mathrm{mg} \mathrm{Zn/kg} \mathrm{DM} \mathrm{(Anon.} \mathrm{1982).} \mathrm{Our} \mathrm{lambs}$ should therefore be provided with enough $\mathrm{Zn}$. Norwegian coastal pastures on average contained $39 \mathrm{mg} \mathrm{Zn/kg} \mathrm{DM} \mathrm{(Froslie} \mathrm{\&} \mathrm{Nor-}$ heim 1983), which was similar to contents in Scottish herbage (Anon. 1982).

Grass $\mathrm{Al}$ has become more soluble in surface waters and is easier absorbed by the plants as a result of acid rain (Alfrey 1986). $\mathrm{Al}$ may interfere with the absorption of several elements, cause neurotoxicity and a microcytic hypochromic anaemia (Alfrey 1986). So far it is difficult to interpret a role of $\mathrm{Al}$ in the pathogenesis of OWLD.

The amount of $\mathrm{Pb}$ found in our samples was within normal limits (Quarterman 1986). It is unknown whether the reduced protein $\mathrm{N}$ to amid $\mathrm{N}$ ratios in OWLD grass may have any significance in the development of the disease. The lack of difference in gramine contents between $\mathrm{S}$ and $\mathrm{H}$ grass probably rule out these alkaloids as cofactors of the OWLD pathogenesis. The lack of difference regarding the other elements given in Table 5 probably also indicates that these are not significant.

The lower contents of trace elements found in the grass in June each year probably reflect the high grass yield resulting in an effect of dilution.

OWLD was associated with pasture grass containing marginal/deficient Co during the first months of grazing. Similar Co values were, however, also found in other pastures, where clinically healthy lambs gained $13 \mathrm{~kg}$ more than the OWLD affected ones during the grazing period. Outbreaks of OWLD are therefore dependant on cofactors. The differences found between $\mathrm{S}$ and $\mathrm{H}$ grass regarding other metal concentrations, especially $\mathrm{Cu}$, may be of significance. 


\section{References}

Anonymous: The nutrient requirements of ruminant livestock. Technical review by an Agricultural Research Council Working party. Commonwealth Agricultural Bureau, Farnham Royal, Slough 1980, 351 pp.

Anonymous: Trace element deficiency in ruminants. Report of a study group under Scottish Agricultural Colleges \& The Scottish Agricultural Research Institutes. Edinburgh 1982, 87 pp.

Alfrey $A C$ : Aluminum. In Mertz W (ed.): Trace Elements in Human and Animal Nutrition, 5th ed., vol. 2, Academic Press, London 1986, p. 399-413.

Andrews ED, Stephenson BJ, Anderson JP, Faithful $W C$ : The effect of length of pastures on cobalt-deficiency disease in lambs. N. Z. J. agric. Res. 1958, 1, 125-139.

Berry PH, Richards RB, Howell JM, Cook RD: Hepatic damage in sheep fed annual ryegrass, Lolium rigidum, parasitised by Anguina agrostis and Corynebacterium rathayi. Res. vet. Sci. 1982, 32, 148-156.

Clark RG, Cornforth IS, Jones BAH, McKnight $L J$, Oliver $J$ : A condition of ovine white liver disease in lambs on irrigated pasture in South Canterberry. N. Z. vet. J. 1978, 26, 316.

Davis GK, Mertz W: Copper. In: Mertz W. (ed.): Trace Elements in Human and Animal Nutrition, 5th ed., vol. 1, Academic Press, London 1987, p. 301-364.

Frank A, Petersson LR: Selection of operating conditions and analytical procedure in multimetal analysis of animal tissues by d.c. plasma-atomic emission spectroscopy. Spectrochim. Acta 1983, 38 B, 207-220.

Froslie A, Norheim G: Copper, molybdenum,zinc and sulphur in Norwegian forages and their possible role in chronic copper poisoning in sheep. Acta agric. scand. 1983, 33, 98-104.

Gardiner MR: The pathology of lupinosis in sheep. Gross- and histo-pathology. Path. vet. 1965, 2, 417-445.

Grimmett $R E$, Melville $J$ : A fluorescent alkaloid in ryegrass (Lolium perenne L). N. Z. J. Sci. Technol. 1943, 25, 149-150.
Halpin C, Caple I, Schroder P, McKenzie R: Intensive grazing practice and selenium and vitamin B12 nutrition of sheep. In: Gawthorne JM, Howell JM, White CL (eds.): Trace element metabolism in man and animals. Springer, Berlin 1982, p. 222-224.

Halvorsen HM: Personal communication, 1989.

Hurley LS, Keen LS: Manganese. In: Mertz W (ed.): Trace elements in human and animal nutrition, 5th ed., Vol. 1, Academic Press, London 1987, p. 185-223.

Marston HR, Thomas RG, Murnane D, Lines $E W L$, McDonald IW, Moore HO, Bull LB: Studies on coast disease of sheep in South Australia. Council for Scientic and Industrial Research, Melbourne Bull. no. 113, 1938, 91 pp.

Marten GC, Jordan RM, Hovin AW: Biological significance of reed canarygrass alkaloids and associated palatibility variation to grazing sheep and cattle. Agron. J. 1976, 68, 909-914.

Martinovich D: Sheep diseases in Northland associated with suspected toxic forage. Proc. N. Z. vet. Ass. Sheep Society 4th Seminar, Faculty of Vet. Sci. Massey Univ. 1974, p. 99-101.

Mason $R W$, McKay R: Ovine white liver disease. Aust. vet. J. 1983, 60, 219-220.

McLaren RG, Lawson DM, Swift RS: The availability to pasture plants of native and applied soil cobalt in relation to extractable soil cobalt and other soil properties. J. Sci. Food Agric. 1987, 39, p. 101-112.

McLoughlin MF, Rice DA, Taylor SM: Liver lesions resembling ovine white liver disease in cobalt deficient lambs. Vet. Rec. 1984, 115, 325.

Mills $C F$, Davis GK: Molybdenum. In: Mertz W (ed.): Trace elements in human and animal nutrition, 5th ed., Vol. 1, Academic Press, London 1987, p. 429-463.

Mitchell RL, Reith JWS, Johnston IM: Trace element uptake in relation to soil content. J. Sci. Food Agric. 1957, 8, Suppl. 51-59.

Mitchell PJ, McOrist S, Thomas KW, McCausland $P$ : White liver disease of sheep. Aust. vet. J. 1982, 58, 181-184.

Norheim G: Personal communication, 1989. 
Quarterman J: In: Mertz W (ed.): Trace Elements in Human and Animal Nutrition, vol. 2, Academic Press, London 1986, p. 281-317.

Richards RB, Harrison MR: White liver disease in lambs. Aust. vet. J. 1981, 57, 565-568.

Robertson $W W$ : Cobalt deficiency in ruminants. Vet. Rec. 1971, 89, 5-12.

Seaman JT: Pyrrolizidine alkaloid poisoning of sheep in New South Wales. Aust. vet. J. 1987 , 64, 164-167.

Siegel MR, Latch GCM, Johnson MC: Acremonium fungal endophytes of tall fescue and perennial ryegrass: significance and control. Plant Dis. 1985, 69, 179-183.

Simons $A B$, Marten $G C$ : Relationship of indole alkaloids to palatibility of Phalaris arundinacea L. Agron. J. 1971, 63, 915-919.

Smith RM: Cobalt. In: Mertz W (ed.): Trace Elements in Human and animal Nutrition, 5th. ed., Vol. 1, Academic Press, London 1987, p. 143-183.

Snedecor $W$, Cochran WG: Statistical methods, 6th ed., Iowa State University Press, Ames, Iowa USA 1967, p. 265-275.

Sutherland RJ: Preliminary observations on the relationship between vitamin $\mathrm{B} 12$ status and ovine white liver disease. Proc. N. Z. vet. Ass. Sheep Soc. 8th Seminar, Canterberry, 1978, p. 13-15.

Sutherland RJ, Cordes DO, Carthew GC: Ovine white liver disease - an hepatic dysfunction associated with vitamin B12 deficiency. N. Z. vet. J. 1979, 27, 227-232.

Suttle NF: Assessment of the mineral and trace element status of feeds. In: Robards GE, Packham RG (eds.): Proceedings 2nd Symposium of International Network Feed Information Centres, Farnham Royal, CAB 1983, p. 211-237.

Ulvund $M J$ : Chronic poisoning in a lamb grazing phalaris arundinacea. Acta vet. scand. 1985, 26, 286-288.

Ulvund MJ: Ovine white-liver disease (OWLD). Trace elements in liver. Acta vet. scand.

Reprints may be requested from: Martha J. Ulvund, State Veterinary Research Station

for Small Ruminants, Høyland, P. O. Box 264, N-4301 Sandnes, Norway.

\section{0a, 31. (Received May 10, 1989; accepted October 9, 1989). \\ 1990a, 31. (Received May 10, 1989; accepted October 9, 1989).}

Ulvund MJ: Ovine white-liver disease (OWLD). Serum copper and effects of copper and selenium supplementation. Acta vet. scand. 1990b, 31, 287-295.

Ulvund MJ: Ovine white-liver disease (OWLD). Pathology. Acta vet. scand. 1990c, 31, 309324.

Ulvund MJ, Pestalozzi M: Ovine white-liver disease (OWLD) in Norway. Clinical symptoms and preventive measures. Acta vet. scand. 1990, 31, 53-62.

Østrem $L$ : Studies in genetic variation in reed canarygrass, Phalaris arundinacea L. I. Alkaloid type and concentration. Hereditas 1987, 107, 235-248.

\section{Sammendrag}

Kvitleversjuke (kobolt/vitamin $B_{12}$ mangel) hos lam. Botanisk og kjemisk sammensetning av

beitegraset.

De viktigste grasartene på sjukdomsbeitene (S) var rapparter (Poa spp.), kveke (Agropyron repens) og vanlig raigras (Lolium perenne), mens kontrollbeitene $(\mathrm{H})$, der lamma hvert år har svært god tilvekst, besto av rapp, rødsvingel (Festuca rubra) og engkvein (Agrostis tenuis). Jorda var surere på H-beitene enn på S-beitene. S-graset inneholdt marginale til deficitte koboltmengder i første del av beitesesongen. I 2 av 3 år hadde S-graset lavere koboltinnhold enn $\mathrm{H}$-graset, men 1 år var koboltinnholdet like lavt $\mathrm{i}$ H-graset. Dette året vokste $\mathrm{H}$ lamma likevel $13 \mathrm{~kg}$ mer iløpet av beitesesongen enn $\mathrm{S}$ lamma. Resultatene indikerer at det må ha vært subklinisk koboltmangel hos $\mathrm{H}$ lamma visse år, og at opptreden av OWLD ikke bare er avhengig av lavt Co innhold i beitet. S-graset hadde signifikant lavere kopper-, molybden-, mangan- og sinkinnhold, lavere protein N/amid N, og høyere aluminium- og jerninnhold. Resultatene viser at marginale koboltmengder eller mangelnivå i graset er av betydning for utvikling av kvitleversjuke, men at interferens av andre faktorer spiller en rolle. 